\title{
Excavating memories: A retrospective analysis of mathematics teachers' foregrounds
}

\author{
Author: \\ Nyna Amin ${ }^{1}$ \\ Affiliation: \\ ${ }^{1}$ School of Education, \\ University of KwaZulu-Natal, \\ South Africa \\ Correspondence to: \\ Nyna Amin \\ Email: \\ amin@ukzn.ac.za \\ Postal address: \\ 9 Normandy Crescent, \\ Westville 3630, South Africa \\ Dates: \\ Received: 23 May 2012 \\ Accepted: 03 Oct. 2012 \\ Published: 05 Dec. 2012 \\ How to cite this article: \\ Amin, N. (2012). Excavating \\ memories: A retrospective \\ analysis of mathematics \\ teachers' foregrounds. \\ Pythagoras, 33(2), Art. \\ \#178, 9 pages. http://dx.doi. \\ org/10.4102/pythagoras. \\ v33i2.178
}

This article offers a retrospective analysis of mathematics teachers' experiences as learners in school to examine their foregrounds. Based on Skovsmose's notion, foregrounds are perceptions of possibilities, impossibilities, hope and despair made by an individual whose life chances are compromised by socio-political adversities and economic deprivation. Since foregrounds are imagined it is not possible to be certain about how the future is realised without engaging in a longitudinal study spanning decades. One way to attempt to do so is through memory work, that is, by excavating the memories of persons who are already living in their foreground. Three mathematics teachers were recruited through snowball sampling to share their memories of teachers of mathematics, learning mathematics in schools and how they envisioned the future. The analysis revealed how exposure to mathematics teaching and learning when they were learners is implicated in shaping the foregrounds of teachers, and the ways in which teacher foregrounds are connected to personal and national development. The participants' narratives confirmed that, although a foreground is shaped by prevailing conditions, a view to a viable future requires an optimism that goes beyond present situations.

\section{Introduction}

There is some evidence that the South African education system is in a crisis. Bloch (2009), for example, sketches in stark detail the ingredients of a 'toxic mix' in education that threatens the good future of the next generation. For a country that inhabits and exhibits the full spectrum of positions simultaneously on a continuum from undeveloped to advanced development, Bloch offers a systems approach to analysing the woes besetting the country: poor teaching, poor learning, dysfunctional schools, ill-prepared and under-prepared teachers, poverty, poor health and nutrition, lack of resources, poor management of schools, problematic education policies, militant professional teacher associations and lack of political will. The crisis Bloch refers to exteriorises challenges that appear to be insurmountable. Although a relativist argument may be made that it depends on which schools and which learners are referred to, Skovsmose (2005) guards against relativist stances: 'Crises belong to reality. They are not merely conceptual constructions, meaning a different way of looking at reality may create a picture we can appreciate' (p. 17).

The crisis in education is most strongly articulated in mathematics as there is, ostensibly, a relationship between mathematics competency and levels of attainment and national development. It is mathematics performance in general that continues to support the notion of a failing education system. Evidence of the importance of mathematics is tangible in the countless official reports (e.g. Department of Social Development, 2010; United Nations Development Programme, 2011) and reports in the popular press (e.g. MacFarlane, 2011; Parker, 2012) concerning educational performance and the lack of readiness of learners to study at tertiary level due to poor mathematics proficiencies.

Underpinned by current grand narratives of a crisis in education, this article offers the personal narratives of three teachers of mathematics to disrupt the domination of negative discourses. The narratives are recollections about the teachers who taught mathematics when they were learners at school. All three participants experienced poverty and deprivation and grew up during a period of political repression, economic hardships and uncertain futures. The challenging circumstances the participants faced are common to most children growing up in ghettoes, and sprawling lowincome townships and settlements. Surrounded by poverty, and deprived of cultural capital, how did they imagine the future? And what made it possible for each one to become a mathematics teacher? The notion of imagining the future, described as a foreground by Skovsmose (2005), is explained in more detail in the next section.

It is important to focus on the mathematics learning experiences of those who currently teach mathematics in schools to complement and destabilise the many systems and meta-analytical insights. The quest to improve mathematics performance in South Africa requires exploration 
of all aspects that have a direct or indirect impact, and even of aspects that may appear to be only remotely connected to learning success. Mathematics teachers, I argue, are not produced in isolation: past experiences and internal and external influences (see e.g. Samuel, 1999), are implicated in the making of teachers and, similarly, of the national development landscape. Indeed, both personal and national developments are connected in and through teachers.

\section{Foregrounds and the South African context}

As in many developing contexts, children in South Africa are expected to have better prospects than the preceding generations. However, the woes besetting South African education are unlikely to be resolved in the short term so there is an urgency to support Skovsmose's proposal that it is more important to know learners' aspirations about ' $[h]$ ow the future might look from the perspective of a ghetto, from the Fourth World, or for a group of disposable people' (Skovsmose, 2005, p. 191).

Skovsmose's description of certain learners as 'disposable people' has specific reference to those whose lives are ravaged by a combination of socio-political adversities and economic deprivation. These are individuals on whom hardships are imposed by contextual complexities and for whom political systems have neither affection nor the will to improve their lives. They have, to state it differently, been relegated to the periphery, perhaps forgotten and ignored by those who wield political control. Under these conditions Skovsmose asks how 'disposable persons' envisage the future. Are their prospects promising or dismal?

Skovsmose's notion of foregrounds (future looking) differs markedly from psychological perspectives that a foreground (object) can be distinguished from its background area, or be reversed or merged. It is also dissimilar to Casati's (2003, p. 283) interpretation of 'representational advantage', that is, the figure (foreground) is more prominent and remembered for longer periods than the ground (background). Skovsmose's notion, by contrast, is allied to socio-political concerns to reveal the aspirations that 'disposable persons' have despite their uninspiring situations, which include a range of possibilities, impossibilities, hope and despair. Interestingly, Skovsmose demonstrates that the future is not necessarily perceived as hopeless and condemned. Furthermore, foregrounds are complex, uncertain and unstable phenomena comprising multiple possibilities, barriers and propensities suggested by a context (background). Foregrounds cannot be predicted and are vulnerable to change even when a context remains unchanged because foregrounds are imagined and mediated by experiences and interpretations of experiences. The imagined future possibilities undoubtedly change as foregrounds shift and change.

How the future is perceived is closely related to development. Two types of development are relevant: personal (as it applies to an individual) and national (as it applies to a nation state). The South African Development Indicators Report
(Department of Performance Monitoring and Evaluation, 2010) lists education and its connection to mathematics achievement as key to national development. The importance accorded to mathematics is not accidental. The development report highlights a drop of $11 \%$ in performance from the Trends in Mathematics and Science Study (TIMSS) of 1999 to TIMSS 2003. Despite criticism raised about the TIMSS studies (see e.g. Bracey, 2000), the development report concludes that 'no matter what index is used South Africa performs poorly in mathematics and science' (2010, p. 51). Of course the development report and TIMSS studies are grand statements about the state of learning mathematics; they do not provide insights about individual teachers and their perceptions of teaching and learning mathematics.

Against this backdrop, I wondered how mathematics played a role at a personal level of development. What kinds of mathematics learning experiences inspire a foreground filled with possibilities or make it improbable? And what are the ways in which to study foregrounds? Studies about 'disposable persons" views of the future could lead to multiple paths of uncertainty. It would be more useful, I presumed, to begin in individuals' foregrounds and to work backwards. Memory work (King, 2000; Onyx \& Small, 2001) presented the means to do so as the inquiry required going back in time to recall how participants viewed the future and its relevance to their present status as mathematics teachers. Conceptualising the study as an inquiry of past memories provided a methodological approach to study foregrounds because teachers, in a way, are already living in the foreground and their stories enable retrospective analyses. Since mathematics is central to development, I chose to work with Black mathematics teachers who were construed as 'disposable children' when they were young. They grew up in the shadows of apartheid, lived in townships 'disfigured by poverty' (Desai, 2002, p. 8), attended poorly resourced schools and were offered a watered-down education, especially in key subjects like Mathematics and Science. Additionally, access to higher education was restricted by political design to a few institutions that admitted Black individuals to a few careers where employment possibilities were viable. Despite the harsh combination of a repressive political system and an adverse socioeconomic context, the participants in this study became teachers of mathematics. They relate personal narratives of unexpected foregrounds that provide insight about the nature of foregrounds. In particular, their narratives enabled an exploration of the links between mathematics teacher foregrounds and teaching, their influence on learner foregrounds and connections to personal and national development.

In essence, this article thus makes two important contributions: methodological and empirical. Firstly, it reports on a study that makes use of memory work to produce narratives as a means to research foregrounds as conceptualised by Skovsmose (2005) and, secondly, it provides empirical understanding of mathematics teacher foregrounds and their entanglement with education, development and learner foregrounds. 


\section{Narratives in mathematics education}

The idea of narratives in mathematics education is not a novel one (see e.g. Doxiadis, 2003; Solomon \& O'Neill, 1998). In practice it is evident in numerous ways: the lives of great mathematicians envelope and underpin the curriculum; narratives of learners have been generated to understand the complexities of acquiring mathematics knowledge (Burton, 2001); problems have been situated in narratives (Scieszka \& Smith, 1995); and teachers' stories have been used for continuous professional development (Jaworski, 1998). Burton (1996) makes the argument that 'a narrative approach to mathematics and its pedagogy is consistent with a view of mathematics as being socially derived and with the understanding of mathematics as being socially negotiable (p. 32).

By contrast, Solomon and O'Neill (1998) argue that the narrative genre is one of the solutions to underachievement in mathematics. It is also a way to provide descriptions that relate to the personal and its impact on an individual's life. In this section, a reading of great, grand, political and foreground genres is offered with personal narratives solicited methodologically for analysis in a subsequent section.

Great narratives refer to stories about outstanding individuals, their anguish and passion, brilliance and innocence, tragedy and triumph, commitment and sacrifice. These are the kinds of stories that supposedly move, inspire and awe as exemplified by early mathematicians like Pythagoras (Gorman, 1979) and Euler (Bell, 1937), the tragic geniuses Abel (Livio, 2006; Turnbull, 1993), Galois (Livio, 2006; Singh, 2002) and Lobachevskii (Gray, 1989), and latter-day giants like Wiles (Singh, 2002) and Nash (Nasar, 2001), whose trials and triumphs have been turned into movies. Fictionalised narratives of great mathematicians (Doxiadis, 2000; Tahan, 1993) have also played a role in inspiring learning about mathematics. It is assumed that mathematics teaching that incorporates the lives of great mathematicians allows learners to make emotional connections to the discipline (Doxiadis, 2003), consistent with the value of storytelling in education in general. It was the move, however, from absolutist to fallibilist philosophies of mathematics education that created more opportunities to present historical narratives of great lives. History constructed from biographical accounts of great mathematicians gave credence to the claim that mathematical knowledge is 'a product of on-going social processes and a reflection of cultural, political, and practical norms and values' (Latterell \& Wilson, 2001, p. 1). Consequently, great narratives can be viewed as social creations supporting particular interpretations of truth.

Grand narratives ${ }^{1}$ (Lyotard, 1979) similarly propose truths about the usefulness (Van Oers, 1996) and values (Wilson, 1986) of mathematics. The British Qualification and Curriculum Authority (2008) asserts that:

1.The notion of grand narrative was coined by Lyotard (1979) to describe the generalisations that supposedly apply universally. He was especially critical of the ways in which diversities, differences and peculiarities were ignored or dispensed with.
Mathematics is fundamental to national prosperity in providing tools for understanding science, engineering, technology and economics. It is essential in public decision-making and for participation in the knowledge economy.... Mathematics equips pupils with uniquely powerful ways to describe, analyse and change the world. (p. 1)

The hegemonic ${ }^{2}$ notion of the importance of mathematics for 'national prosperity' ensures that access to careers in the medical, health and physical sciences, and the economic, technological and engineering fields is limited to those who succeed in the discipline. Furthermore, international studies and national schooling agendas and development goals are shaped by performance in mathematics. For example, South Africa's position at the bottom of performance league tables in the TIMSS studies of 1995 and 1999 (Howie, 1999, 2001) has placed intense focus on mathematics and science as keys to national development and access to high status occupations.

In recent years, politicised narratives of mathematics (e.g. Adler, 2001; Apple, 1995; Keitel, 1998; Skovsmose, 1994; Vithal, 2003) questioned the ways in which social injustices operate and proposed possibilities for recourse. The focus is on philosophies and practices that bring a political dimension to teaching and learning and this has expanded the traditional realm of mathematics in classrooms beyond pure discipline matters to include socio-political and cultural aspects and notions. The education of girls (Walkerdine, 1989), equity (Vithal, 2002) and race and ethnicity (Lim, 2008) are some issues central to critical examination of Mathematics curricula and teaching practices in the discipline. The mathematics classroom the literature suggests is implicated in reproducing iniquities, and in marginalising those most vulnerable.

The literature perused offers three uses in the analysis of personal narratives of the participants in this study. The literature on great narratives which lauds high intelligence and ability for mathematics learning will be interrogated for its role in mathematics teachers' foregrounds. Literature on grand narratives of mathematics as a discipline provides a template against which the experiences of participants will be probed for the effects of national agendas and inspirational stories on mathematics teachers' foregrounds. Finally, the ideas from politicised narratives will be deployed to scrutinise mathematics teaching influences on the barriers and limitations on 'disposable' individuals' foregrounds.

\section{Producing narratives}

For an inquiry purporting to offer an alternative to systems approaches and large-scale studies, a method commensurate with qualitative research was chosen. The intention was to produce narratives that enabled an analysis of teachers' foregrounds. To produce narrative data meant deploying a social method that would encourage participants to talk about their past as well as their present experiences. I opted for three participants using a snowball technique.

2. Hegemony is an idea that dominates through a combination of power (ideological truth) and complicity (by those who do not recognise ideological truth). 
The usefulness of the snowball approach was twofold: it allowed me to carefully identify and search for a participant to fit the profile of a 'disposable' person during childhood and it invited participant assistance with identification and recruitment of two more individuals. The first participant was known to me as a fellow mathematics teacher. He referred me to the second participant and she referred me to the third individual.

The participants were three black teachers. The selection of participants was deliberate as these individuals were schoolgoers during the apartheid era of the 1970s, a period of intense political oppression for Black people in the country. During that time, the schools they attended were generally poorly resourced with unqualified or under-qualified teachers, and the curriculum was narrow and inadequate. Future possibilities were compromised because there were limited opportunities for upward mobility and fewer career choices. The participants, marginalised by the politics of race, space and place could, in a sense, be conceptualised as 'disposable' individuals in the way Skovsmose intended.

The three participants, Aziz, Sindiswe and Nisha (pseudonyms), a man and two women, have each been teaching mathematics in high schools for Black learners for an average of 28 years. Aziz teaches at a suburban school in KwaZulu-Natal, whilst Nisha and Sindiswe teach at township schools in Gauteng. Each came from a deprived socio-economic background. Aziz's father was a recovering alcoholic, Nisha was an orphan and Sindiswe's father was unemployed for a long time. All three attended schools in KwaZulu-Natal during their childhood and now they all teach at schools they described as having poor and deprived contexts, serving children whose lives are comprised by socio-political and economic adversities. Aziz is the most experienced (32 years) and Sindiswe the least (26 years). They have known each other for about 15 years and meet each year at a national mathematics conference.

The data was generated through unstructured interviews, which allowed for probing and some latitude to hone in on insightful experiences. Two telephonic interviews were conducted with each participant. Telephone interviews were convenient for two reasons:

1. Nisha and Sindiswe teach in a province approximately $600 \mathrm{~km}$ away, making face-to-face interviews a costly task.

2. Not knowing them meant anonymity was assured and this, presumably, encouraged them to speak freely.

Aziz was also interviewed telephonically to ensure consistency of data production.

The ideas explored in the interviews were related to understanding their past (as learners of mathematics) and present (as teachers of mathematics). Their stories, reconstructed from interviews as first-person narratives to enhance the presence of the teller of the story, that is the research participant, are interpretations of their past experiences inside school and outside of school. The stories are not evaluated for their truth claims because memories of the past are not objective or untainted; they are reconstructions, interpretations and reinterpretations, reflections, and perhaps even fictionalised accounts. Whether, objective, subjective or fictional, it is the expressed meanings constructed by participants as experiences that are valued and, to that extent, accepted as personal truths as opposed to forensic truths ${ }^{3}$ for the purpose of analysis.

\section{Ethical considerations}

Permission to conduct fieldwork and ethical clearance was applied for and granted ${ }^{4}$. Participants were contacted, informed about the study and invited to volunteer their involvement in the study. Before and during the interviewing process, care was taken to ensure that participants were not coerced or compelled to participate or to answer questions they did not want to. Afterwards, participants were given access to transcripts of the recorded interviews and to the narratives constructed from the transcripts. None of the participants made changes to the narratives.

\section{Mathematics teachers' narratives}

Three narratives were constructed from transcripts of recordings of each interview. Each narrative recalls a participant's encounters with mathematics. The narratives are reconstructions with fragments that I deliberately selected to tell a story for the purposes of the inquiry. The narratives do not contain data not offered by participants. Although the data were restructured by shifting the order of statements and edited for clarity (the removal of ' $\mathrm{um}^{\prime}$ ' and repetitious use of words like 'he never told, he never told us'), they were not augmented, although portions of the interviews, for example about the weather and discussions about colleagues which were not related to the themes discussed in this article, were omitted.

\section{Sindiswe}

Pythagoras was my mathematics teacher. I know everybody is surprised when I say that. In primary school I learnt a little bit about numbers and the four main operations. I was fascinated by numbers. But when I got to high school geometry was a new field. If I remember correctly, I hadn't even heard the word geometry before. And there was this maths teacher who spoke a lot about Pythagoras. He referred to him as the greatest mathematician. We were very interested. Who was this great mathematician, and what made him great? But he never told us. He walked around like a professor and used big words that we could not understand like 'integers' and 'complex numbers'. He said only he knows about mathematics and he could decide whether we passed or failed. Almost all the children in the school failed mathematics. He said we were too stupid to do mathematics. I believed him, for a while. Fortunately, my Dad got a job

3.Posel (2004) provides a theorisation of the four kinds of truth (forensic or factual truth, personal or narrative truth, social or experiential truth, and healing truth) generated by South Africa's Truth and Reconciliation Commission.

4.The application for ethical clearance was approved by the University of KwaZuluNatal's Humanities and Social Sciences Research Ethics Committee. 
with a big company and we had to move.' In my new school I learnt geometry, algebra, trig and graphs. I passed matric with a B in maths. Now I teach maths. I really want to visit old Pythagoras. I wonder how he will react when I show him the maths results of my students - most of them pass maths. The kids I teach will change this country with their mathematical abilities. I am glad to play a part. I might never have been a teacher if I had remained in that school.

\section{Aziz}

I have been teaching mathematics for close to thirty years. It is heaven and hell, especially in a poor school like ours. The kids find it so hard. Of course there are those who enjoy it and do very well, but most of the time it is so frustrating. I think a lot about why they relate negatively to mathematics. A lot of their problems have to do with the home. When I was young, my father always told us that mathematics opens doors and careers. We could be anything we want to be as long as we did well in mathematics. Whenever he drove us around town, he made us point out numbers, he explained how mathematics was used in the construction of roads and buildings. We identified the usefulness of numbers in shops and stores, and while we were shopping he made us calculate GST [general sales tax] on each item. Those were the days before VAT [value added tax]. I think I was made to feel so comfortable with numbers and calculation so that when we did mathematics in school it seemed so normal and so easy to understand. I am grateful to my dad for helping me to get to grips with maths. There was not a single teacher in primary school or high that was qualified to teach properly. Some of them knew less than us. The funny thing is that I became a teacher. Because of the realities, I could only become a teacher. You couldn't just decide to go to varsity [university] and do law or anything. So, mathematics opens doors, if the doors are there to be opened.

Nowadays I don't think the children in my class have quite the same opportunities to play with numbers. I think that is the key, playing with numbers, otherwise it is so vague and abstract. The children here believe that they will never master the subject. So this country will continue to flounder and fail. We will never measure against international standards and competencies. Mathematics is so important and yet so unvalued.

\section{Nisha}

You know, I was once a learner, a very, very good student, I might add, but a very weak maths learner. So why was I weak in maths? Let me tell you. It was the maths teachers. They were unkind and very unsocial. They exuded and expected perfection. One of the teachers spent so much time just instructing us on how to write numbers. He was fascinated by the number 2 and after he wrote the number on the board he would stand back and admire it and say something like, 'Isn't that just the most beautiful symbol? It's curvy and stylish, delicate and a symmetrical piece of art'. Isn't it strange for a mathematician to describe a science as an art? Stranger yet was the teacher who killed us with mental tests, both oral and written. We were never given enough time and were made to feel stupid when a test was not completed in the time limit. She stressed speed and her famous words were 'Quick, what's the answer?'. Another character, in high school, would stand in front of the board, mumble to himself and voila, solve the problem, but he could not explain the steps. Often I tried to make sense, but the logic defied me. I was kept out of the inner world of mathematics. I came to grips with maths through my own initiatives. I literally taught myself. Come to think about it, I'd forgotten these episodes and perhaps it explains the reasons I spend so much time explaining, or trying to make maths fun. Maybe that's why I chose to be a maths teacher. My subconscious memories want me to make it work for kids. Would I have ever thought of becoming a teacher? I don't think so. The possibility was as remote as climbing Mount Everest. But I believed in myself and here I am. My learners will never think of me as a bad maths teacher.

\section{Discussion}

\section{Mathematics teachers' experiences}

Each participant's narrative recounts memories of days when they were learners. In other words, these are teachers' memories of learning mathematics. Their stories provided insights of the formation of subjects who resisted, despised and embraced mathematics. Mathematics, it appears, was the site of personal struggles and achievements. The analyses of the three narratives are restricted for this paper to three themes: foregrounds and experiences of learning mathematics, mathematics and development, and, images of mathematics teachers. The final section hones in on the connection between mathematics, foregrounds and development.

\section{Foregrounds and experiences of learning mathematics}

The data suggests that the three participants were inspired to learn mathematics in dissimilar ways. Sindiswe's experiences were mediated by two individuals who were radically unalike. Teacher 'Pythagoras' displayed arrogance, imbued with notions of elitism. In an era and an arena when education was highly valued in unprivileged apartheid spaces because Black persons had limited access to education, he was able to strut about and act as a gatekeeper of sacred knowledge. Sindiswe related how it was impossible to know whether he had content but not pedagogical knowledge or whether his cryptic musings about the Greek Pythagoras was a facade that veiled his ignorance of mathematics. A fortuitous move to another city activated the acquisition of crucial mathematical knowledge. A change of school reversed teacher Pythagoras' evaluation that she 'was too stupid to do maths'. A change of teachers enabled personal development and growth. It is reasonable to conclude then that foreground too was changed, making teaching as a career possible.

Aziz's memories of learning mathematics were located outside school. His father taught him mathematics. Based on his experiences in school he recounted that the methods 
his father used were unusual when compared to those used in school. The lessons were not planned and occurred incidentally and opportunistically. His father used everyday, practical living to teach him. Whereas Sindiswe and her peers were explicitly told that they were 'too stupid', Aziz thought the 'mathematics teachers were stupid' as they could not make learning fun. During the interviews he related how he 'sailed through' mathematics in high school because of his father's tutoring. Aziz's narrative related learning experiences that were joyful and his foreground reflected possibilities to 'be anything he wants to be'.

Nisha's experiences of learning mathematics were not ideal as her teachers were idiosyncratic and eccentric and kept her 'out of the inner world of mathematics'. She experienced teachers who were technical perfectionists, or interested in the aesthetics of numbers or could not teach problem solving. The consequence was that she became her own teacher. Nisha's negative experiences of learning in school led to positive outcomes, making her a self-reliant and independent learner. Her foreground was of her own making, as she was not reliant on external structures and processes.

The grand narrative about learning mathematics is that it requires teachers. But what the participants' personal narratives reveal is that the mathematics teacher is not necessarily a schoolteacher; they can be a parent or a learner too. Each teacher, whether a professional, a parent or a learner, does influence the way the future is ruined or rescued. Learning mathematics can be inspired by school, home or self. All paths have the same effect, that is, learning does take place, but school learning is hegemonic in the Gramscian (1977) sense of being valued above other learning spaces even though 'mathematics education is everywhere' (Skovsmose, 2005, p. 2009).

\section{Mathematics and development}

Based on teachers' memories, two themes recur in the narratives. The first relates to mathematical ability and personal development and the second to mathematics and national development. The memories of schooling were similar for both female participants. Sindiswe and Nisha were made to feel 'too stupid to do mathematics'. The idea that girls do not achieve as well as boys in school because girls are wired for language and boys for abstract reasoning has been disproved (Halpern, Benbow, Geary, Hyde \& Gernsbacher, 2007). Perhaps the answer lies in social processes: girls are marginalised in class because boys dominate teachers' attention and gender norms ensure that girls learn to be girls and deny their ability (Paechter, 2000). If so, we can deduce that Sindiswe's and Nisha's foregrounds, from these perspectives, are predetermined by a combination of social, cultural and biological forces. But Sindiswe's and Nisha's narratives demonstrate that the future can either be ruined by poor teaching or rescued through self-intent. They acquired mathematical competency through change of fortune or self-motivation, resilience and tenacity.
Aziz's experiences of mathematics are also about poorly qualified teachers who could not make learning fun and it was the education provided by his father that compensated for this poor teaching in school.

The narratives reveal that possibilities and impediments to national development were contingent. Sindiswe and Nisha were optimistic about the future based on their contribution to mathematics teaching. Remembering their own experiences of feeling stupid yet now able to produce successful mathematics learners, they felt the future was better: that the learners they taught had far more competency than they did as learners. Aziz, by contrast, who enjoyed 'play[ing] with numbers', and who now teaches 'vague and abstract' mathematics, does not believe that mathematics will be mastered. One can infer that he is reliant on parents to contribute to mathematics learning and his assumption that parents do not explains the poor performances on standardised tests. Although the logic deployed by Aziz to explain poor performance is questionable, his claim is closer to the reality of the present (Howie, 2001) than the experiences of Sindiswe and Nisha.

All three participants attested to a concern for development: Sindiswe and Aziz commented on mathematical performance and national development and Nisha on mathematical performance for personal development. Sindiswe voiced optimism for the country's progress because she believed that her role as teacher was a crucial contribution to learning success. Aziz, by contrast, feared that the outlook for the country was bleak because the children in his class were not supported by their parents. In his opinion, his role as teacher was not as vital as are parents' roles. Nisha, on the other hand, judged personal determination and self-reliance as key to personal growth and success.

One explanation for the sweeping statements uttered by each participant may have to do with their awareness that they teach a high stakes discipline. Those who teach subjects like mathematics or literacy are more scrutinised than teachers of, say, history or music. These are the subjects that are most mentioned in the press because mathemacy and literacy are important competencies for success in contemporary times. Therefore, it is not surprising that participants made huge claims about learner foregrounds. Foregrounds were interpreted as promising (Sindiswe and Nisha), or ruined (Aziz).

\section{Images of mathematics teachers}

Discursive images of mathematics teachers emerged from the narratives. Sindiswe's image was a great individual, but one whose greatness was symbolised by a name, arrogance and power. 'Pythagoras' did not teach mathematics; instead he explained how he wielded power: he tantalised learners with his knowledge of mathematical concepts and terms but did not follow through with teaching. He also controlled the pass rate. He was the 'professor' in his ivory tower or the 'imitator' who pretended to know mathematics. Sindiswe came to this 
realisation only after exposure to another context. In this instance, the importance of having a comparative basis can be seen in the change of foreground - the perception of a future teaching mathematics was not possible until she experienced success in mathematics. Consistent with research findings (Skovsmose, Alrø \& Valero in collaboration with Silvério \& Scandiuzzi, 2007) mathematics teachers' experiences reveal that foregrounds are not fixed: they change with changing conditions.

Aziz's teacher was the parent-as-teacher, a loving guide and inspirer who turned mathematics into a game outside the classroom. Aziz as a teacher-as-teacher conjured an image of frustration as he reflected on his own practice. Aziz's portrayal was self-generated: someone who was disappointed, frustrated and pessimistic. He was not able to appropriate the methods of teaching employed by his father in his own classroom. He is Delpit's (1988) version of the teacher who 'teaches other people's children' - disinterested in their foregrounds.

Nisha provided a number of images of mathematics teachers. One was a 'perfectionist' who was more interested in the aesthetic proportions and forms of numbers. Another image was that of a teacher who was unkind and unsocial, made excessive and unreasonable demands and constructed mathematics as an obscure and abstract subject, compromising and perhaps denying hope and possibility. A third was an image of a teacher who made mathematics a mystery, with secret processes taking place in the mind, as he did not teach algorithmic processes. He was the brilliant teacher, but could not communicate or make visible the mysteries of mathematics. These teachers, one can conclude, sabotaged Nisha's foreground.

Images of teachers were powerful sources that stirred or stifled the foregrounds imagined by Aziz, Nisha and Sindiswe. When life conditions were severe, as they were during apartheid, Nisha, Sindiswe and Aziz needed teachers who made mathematics inviting; their foregrounds, instead were shaped by chance or luck.

\section{Mathematics, foregrounds and development}

Undertaking a retrospective analysis of teachers' foregrounds has yielded a number of insights about mathematics teaching, mathematics teachers' foregrounds and the links to development. Tracking early experiences in school unveiled the ways the participants were inspired to embrace mathematics or to resist it. Who taught mathematics and how it was taught opened or closed foregrounds. Furthermore, mathematics teachers were not necessarily trained and credentialed professionals. Of the three participants, one was taught by a parent and another taught herself. These tangential learning opportunities liberated their imaginations which could have been constrained by context and background.

The importance of gazing at the lives of mathematics teachers lies in its connection to learner foregrounds. As explained by
Skovsmose (2005), teachers are ideally positioned to take on the responsibility of enabling learners to imagine a better future. What comes through is that more than thirty years ago, when Sindiswe, Aziz and Nisha were learners in school, what were their foregrounds, that is, how did they see their future? For a period of time, Sindiswe and Nisha faced poor prospects; changes in context and personal belief changed the way they saw their futures. By contrast, Aziz's positive encounters with mathematics and messages to 'be anything' might have foretold a future that surpassed that envisioned by Nisha and Sindiswe. But the analysis reveals a reversal of sorts. Despite advantage or disadvantage, positive or negative encounters, good or poor teaching, they all became teachers. That is, no matter what foreground each imagined, they ended up with remarkably similar prospects. The reversal is in their outlook or foregrounds for their learners and the country. Sindiswe and Nisha, who had more reason to be unsuccessful, embraced teaching with confidence, enjoyed their roles and believed that they teach to make a difference to both learners and the country. By contrast, Aziz, the benefactor of a progressive approach to learning mathematics outside of school, was pessimistic about the future. It appears that his early experiences resulted in limited success. He resisted the role of inspiring, creative teacher as he believed those functions were the obligation of parents. The absence of parent involvement in the learning of mathematics, in his opinion, meant a bleak future for learners and the country. It also communicated his impotence to make a difference. Undoubtedly, the conclusion one can draw is that teachers' outlooks are implicated in the foregrounds of children.

What explains Aziz's (and Sindiswe's) choice of career if the grand narrative about mathematics and success is to be relied on? Why did they not aspire for careers such as scientists, medical doctors or economists? What explains their choice to pursue teaching which is, by contrast, less prestigious and provides a moderate income? One has to remember that when the career choice was made more than three decades ago by all three participants, South Africa was under apartheid rule. In Aziz's words, all 'doors were not open' to Black people. In spite of good results, Black persons could not pursue any occupation they desired as there were severe restrictions on access to higher education and work prospects. As disposables of the apartheid era, Aziz's, Sindiswe's and Nisha's foregrounds were already constrained by political ideology. It required personal belief in their own ability for them to become teachers. What is significant about the achievement of these individuals is that they chose to become mathematics teachers despite experiences of poor teaching at school. A foreground can thus be seen as a combination of context, education and personal belief to perceive prospects. The context is both political and personal. 'Disposable' persons do not choose their context; it is imposed. The context, in this case, had structural impediments, reflecting social, economic and political dimensions beyond their control. In a sense, a foreground is shaped by prevailing conditions and to have a view of a viable future requires an optimism that goes beyond present situations. Such optimism is doubtful when 
the present is so consumed with socio-economic hardships that possibilities cannot be imagined. Perhaps it requires the mediation of teachers for those marginalised by socioeconomic, political and cultural impediments to envision a future with possibilities. Based on the narratives it seems that teachers like Sindiswe and Nisha, who transcended the bleakness of their own situations to rescue their futures, are ideally placed to inspire those growing up in situations of adversity.

If we accept that a foreground is not perceived in isolation, that it is a combination of self with others, context and structures, then we can assert the importance of education in general and mathematics in particular for personal and national development. National development does not occur in a vacuum with national policy and programme drivers. South Africa's attempts through curriculum change, regulating teachers' work through the setting of norms and standards and progressive methods of assessment have not improved the educational outcomes for those most affected by socio-economic disadvantages. The answer, based on the experiences of Nisha and Sindiswe, is that it perhaps lies at the level of personal development efforts. Individuals, I want to argue, be they teachers or learners, who take charge of their own development are more likely to be vital constituent parts of national development as attested to by the narratives of Nisha, who overcame personal and political challenges, and Sindiswe, who displaced bad memories of poor teaching with successful experiences. Consequently, personal and national developments are in a symbiotic relationship, connected to each other; a change at either level has an impact on both levels. National and personal development cannot be isolated; their connections are intricate and non-dissociative and both play a role in an individual's foreground. Ultimately, the grand narrative, which is also a politicised narrative connecting mathematics achievement and national development, is dependent on personal narratives of optimism, resilience and beliefs.

In terms of great and political narratives, teachers are more likely to be inspired by local and contemporary individuals, such as a parent or a teacher, as evidenced by Aziz. Sindiswe's memories about teacher Pythagoras are unusual. Although it may seem curious, she is more likely to make the connection with a caricature of a teacher she once knew rather than with the Greek mathematician. It appears that the lives of great mathematicians are far removed from the lives of children in poor and deprived contexts and unlikely to contribute to viewing a promising future. By contrast, political narratives are subtle, suggesting that a high-stakes discipline like mathematics colonises a grand discourse around the discipline rather than paying adequate attention to issues of poverty, marginalisation and social oppression. Aziz, Nisha and Sindiswe were not beneficiaries of liberating and transformative discourses which are implicated in limiting or opening foreground possibilities. Whilst some may argue that the teaching of mathematics is unrelated to political agendas, Vithal's (2003) study highlights the way a teacher is pivotal in bringing issues of a socio-political dimension into the mathematics classroom.
To conclude, the production of personal narratives has been useful to map the experiences of teachers and to provide some insight into how they understand the learning of mathematics and to track the consequences of that learning in their adult lives. Through the lived experiences of mathematics teachers, it is possible to extract the grand and political narratives that inhabit mathematics teaching and learning. Teachers' narratives may be a way to understand mathematics teaching and also its connection to foregrounds and development. The claims, however, are emergent, suggesting that mathematics performance, teaching and learning are complex and unravelling their many aspects, through teacher narratives, requires more research.

\section{Acknowledgements}

I am grateful to Renuka Vithal for inviting me to respond to Ole Skovsmose's presentation at the symposium Mathematics, education, democracy and development: Challenges for the 21st Century on 04 April 2008 at the University of KwaZulu-Natal, Durban, which inspired the empirical work underpinning this article.

\section{Competing interests}

I declare that I have no financial or personal relationship(s) which may have inappropriately influenced me in writing this article.

\section{References}

Adler, J. (2001). Mathematics in multicultural classrooms. Dordrecht: Kluwer Academic Publishers.

Apple, M.W. (1995). Taking power seriously: New directions in equity in mathematics education and beyond. In W.G. Secada, E. Fennema, \& L.B. Adajian (Eds.), New directions for equity in mathematics education ( $p p$. 329-348). Cambridge: Cambridge University Press.

Bell, E.T. (1937). Men of mathematics. New York, NY: Simon and Schuster.

Bloch, G. (2009). The toxic mix: What's wrong with South Africa's schools and how to fix it. Cape Town: Tafelberg.

Bracey, G.W. (2000). The TIMSS “Final year" study and report: A critique. Educational Researcher, 29(4), 4-10. Available from http://www.jstor.org/stable/1176452

Burton, L. (1996). Mathematics, and its learning, as narrative - a literacy for the twenty-first century. In D. Baker, J. Clay, \& C. Fox (Eds.), Challenging ways of knowing in English, Maths and Science (pp. 29-40). Sussex: Falmer.

Burton, L. (2001, August). Children's mathematical narratives as learning stories. Paper presented at the European Conference on Quality and Early Childhood Education, Alkmaar, Netherlands.

Casati, R. (2003). Representational advantages. Proceedings of the Aristotelian Society, 103, 281-298. http://dx.doi.org/10.1111/j.0066-7372.2003.00073.x

Delpit, L. (1988). The silenced dialogue: Power and pedagogy in educating other people's children. Harvard Educational Review, 58(3), 280-298.

Department of Performance Monitoring and Evaluation. (2010). Performance indicators. Available from http://www.info.gov.za/view/DownloadFileAction?id=137217

Department of Social Development. (2010). Vulnerability of children and poor families to the economic recession of 2008-2009. The Department of Social Development, South Africa and the United Nations Children's Fund. Available from http://www. unicef.org/southafrica/SAF_resources_vulnerabilityecon.pdf

Desai, A. (2002). We are the poors: Community struggles in post-apartheid South Africa. New York, NY: Monthly Review Press.

Doxiadis, A. (2000). Uncle Petros and Goldbach's conjecture. New York, NY Bloomsbury.

Doxiadis, A. (2003, January). Embedding mathematics in the soul: Narrative as a form of mathematics education. Paper presented at the Third Mediterranean Conference of Mathematics Education, Athens, Greece. Available from http:// www.apostolosdoxiadis.com/en/files/essays/embeddingmath.pdf

Gorman, P. (1979). Pythagoras - a life. London: Routledge and Kegan Paul.

Gramsci, A. (1977). Selections from political writings, 1910-1920. London: Lawrence \& Wishart. 
Gray, J. (1989). Words out of nothing: A course in the history of geometry in the 19th century. London: Springer.

Halpern, D.F., Benbow, C.P., Geary, D.C., Hyde, J.S., \& Gernsbacher, M.A. (2007). The science of sex differences in science and mathematics. Psychological Science in the Public Interest, 8(1), 1-51. Available from http://www.psychologicalscience. org/journals/pspi/pspi_8_2 editorial.pdf

Howie, S.J. (1999). Challenges facing reform of science education in South Africa. What do the TIMSS results mean? In S.A. Ware (Ed.), World Bank series on science education in developing countries (pp. 199-215). Washington, DC: World Bank. Available from http://projects.edte.utwente.nl/smarternet/version2/cabinet/ ware/14-howie.pdf

Howie, S.J. (2001). Mathematics and science performance in Grade 8 in South Africa 1998/1999: TIMSS-R 1999 South Africa. Pretoria: Human Sciences Research Council.

Jaworski, B. (1998). Mathematics teacher research: Process practice and the development of teaching. Journal of Mathematics Teacher Education, 1(1), 3-31. $\mathrm{http}: / / \mathrm{dx}$.doi.org/10.1023/A:1009903013682

Keitel, C. (1998). Social justice and mathematics education: Gender, class, ethnicity, and the politics of schooling. Berlin: Freie Universität Berlin.

King, N. (2000). Memory, narrative, identity. Remembering the self. Edinburgh: Edinburgh University Press.

Latterell, C.M., \& Wilson, J.L. (2001). The mathematician and the sociologist in dialogue: New perspectives on the learning of mathematics. Available from http://aabss.org/Perspectives2001/Latterell2001.jmm.html

Lim, J.H. (2008). The road not taken: Two African-American girls' experiences with school mathematics. Race, Ethnicity and Education, 11(3), 303-317. http://dx.do . org/10.1080/13613320802291181

Livio, M. (2006). The equation that couldn't be solved: How mathematical genius discovered the language of symmetry. London: Souvenir Press.

Lyotard, J.F. (1979). The postmodern condition: A report on knowledge. Manchester Manchester University Press.

MacFarlane, D. (2011, March). Report portrays 'a tragic picture' of South Africa's education system. Mail \& Guardian Online. Available from http://mg.co.za/ article/2011-03-29-report-portrays-a-tragic-picture-of-sas-education-system

Nasar, S. (2001). A beautiful mind: The life of mathematical genius and Nobel Laureate John Nash. New York, NY: Simon and Schuster.

Onyx, J., \& Small, J. (2001). Memory work: The method. Qualitative Inquiry, 7, 773-786. http://dx.doi.org/10.1177/107780040100700608

Paechter, C. (2000). Changing school subjects: Power, gender and curriculum. Buckingham: Open University Press.

Parker, F. (2012, January 05). Worrying trends hammer matric pass rate. Mail \& Guardian Online. Available from http://mg.co.za/article/2012-01-05-worryingtrends-hamper-high-matric-pass-rate
Posel, D. (2004). Truth? The view from South Africa's Truth and Reconciliation Commission. In N. Tazi (series Ed.), Truth: For a different kind of globalization (pp. 3-25). Cape Town: Double Storey.

Qualification and Curriculum Authority (2008). National curriculum for mathematics. The importance of mathematics. London: Qualification and Curriculum Authority. Available from http://webarchive.nationalarchives.gov.uk/20100612050234/ nationalstrategies.standards.dcsf.gov.uk/node/16073

Samuel, M.A. (1999). Words, lives and music: On becoming a teacher of English Unpublished doctoral dissertation. University of Durban-Westville, Durban, South Africa.

Scieszka J., \& Smith, L. (1995). Math curse. New York, NY: Penguin.

Singh, S. (2002). Fermat's last theorem. London: Fourth Estate.

Skovsmose, O. (1994). Towards a philosophy of critical mathematics education Dordrecht: Kluwer Academic Publishers.

Skovsmose, O. (2005). Travelling through education: Uncertainty, mathematics, responsibility. Rotterdam: Sense Publishers.

Skovsmose, O., Alrø, H., \& Valero, P. in collaboration with Silvério, A.P., \& Scandiuzzi, P.P. (2007). "Before you divide you have to add": Inter-viewing Indian students" foregrounds, In B. Sriraman (Ed.) International perspectives on social justice in mathematics education. The Montana Mathematics Enthusiast Monograph 1, 151-168. Available from http://www.math.umt.edu/tmme/Monograph1/ Skovsmose_etal_FINAL_pp151_168.pdf

Solomon, Y., \& O'Neill, J. (1998). Mathematics and narrative. Language and Education 12(3), 210-221. http://dx.doi.org/10.1080/09500789808666749

Tahan, M. (1993). The man who counted: A collection of mathematical adventures. (A. Reid, \& L. Clark, Trans.). Edinburgh: Cannongate Press.

Turnbull, H.W. (1993). The great mathematicians. New York, NY: Barnes and Noble Books.

United Nations Development Programme. (2011). Human development Report 2011. Sustainability and equity: A better future for all. New York, NY: United Nation Development Programme. Available from http://www.gm.undp.org/HDR_2011_ EN_Complete.pdf

Van Oers, B. (1996). Mathematics education and the quest for meaning. In L.P. Steffe, P. Neshar, P. Cobb, G.A. Goldin, \& B. Greer (Eds.), Theories of mathematical learning (pp. 91-113). Hillsdale, NJ: Lawrence Erlbaum.

Vithal, R. (2002). Differentiation, in contradiction and co-operation, with equity in mathematics education. African Journal of Research in Mathematics, Science and Technology Education, 6, 1-20.

Vithal, R. (2003). In search of a pedagogy of conflict and dialogue for mathematics education. Dordrecht: Kluwer Academic Publications.

Walkerdine, V. (1989). Femininity as performance. Oxford Review of Education, 15(3), 267-279. http://dx.doi.org/10.1080/0305498890150307

Wilson, B.J. (1986). Values in mathematics education. In P. Tomlinson, \& M. Quinton (Eds.), Values across the curriculum (pp. 94-108). Lewes: Falmer Press. 